\title{
CURRENT TRENDS AND DEVELOPMENTS IN THE INVESTMENT PRACTICES OF ENDOWMENTS AND PENSION FUNDS
}

\begin{abstract}
JAMES W. WoOster, JR*
During the inflationary period of the past ten years, and particularly during the more violent phase of the past five years, the most immediate and pressing problem of the investment managers of endowed funds has been to attempt to increase income at a rate commensurate with the decrease experienced in the purchasing power of the income received. Most endowed funds have succeeded only partially in maintaining their income as expressed in terms of what that income can accomplish. Some, however, have been much more successful in this respect than have others. The reasons behind this variation in results afford an interesting picture of conflicting investment theories and practices.

In speaking of "endowments," or "endowed funds," or of "pension funds," it is important to realize that one is not speaking of a homogeneous entity, but rather of a group of capital aggregations having some, but far from all, common characteristics. It is, therefore, not possible to speak with definiteness and exactness of the total dollar amount of such "endowed funds," as one can speak, for example, of the total of commercial bank deposits. The total size of "endowments" in this country is conditioned to a considerable extent by the definition applied to "endowments." Even after a satisfactory definition has been agreed upon, there still remains the fact that there is no central reporting agency or association having contacts with endowment or pension funds.

In general, endowments fall into one of several generic groupings. Institutions of higher education, chiefly colleges and universities, form one such group. The r95I World Almanac ${ }^{1}$ lists 193 colleges with endowments of 2 million dollars or more, the total endowments of these 193 colleges having a reported value in excess of $\mathrm{I} 1 / 2$ billion dollars. Philanthropic foundations with assets of I million dollars or more are listed in the I951 World Almanac in the number of 35. Their total assets exceed $x \frac{1}{2}$ billion dollars. ${ }^{2}$ Many hospitals depend upon income from endowment to help meet annual operating deficits. There are over 6,500 registered hospitals in the United States, ${ }^{3}$ and although their total of endowed funds is not available, there are many metropolitan hospitals whose known endowments run into multiple millions of dollars. The growth of pension fund assets is a relatively new phenomenon. No

* A.B. 1926, Dartmouth College. Author, Banker's Handzook of Bond Investment (1939). Member of faculty, Graduate School of Banking, Rutgers University. Financial Associate, The Commonwealth Fund.

1 The World Almanac 577-578 (195I).

Id. at 587-590.

Id. at 439 .
\end{abstract}


figures are published on the total principal amount of such funds, but underwriters of investment securities will attest to the importance of such funds as prospective purchasers of securities. The rapid asset growth of pension funds, and the "new money" which they regularly have available for investment, gives a dynamic character to their investment decisions and operations. One such pension fund reputedly has I million dollars a week available for investment.

The total dollar size of endowed funds is obviously substantial. However, it is not size alone, nor even predominantly size, which gives these accumulations of capital their greatest significance. In an economy where the education, health, and welfare of the citizens are becoming of increasing interest to government-federal, state, and local -the value and the importance of private, independent agencies and institutions in these fields increases. The strength and vitality of these privately endowed organizations for the public good become a matter of general interest and concern. The ability of most of these eleemosynary institutions to continue to serve the public is dependent upon the earning power of their invested, endowed funds.

A generation ago, the traditional form of conservative investments for widows, for orphans, and for endowments, was corporate bonds. In the year 1924 corporate bonds of about $2 \mathrm{I}$ billion dollars were outstanding. ${ }^{4}$ In New York State only I6.I per cent of these bonds were legal investments for savings banks and trust funds, and no public utility or industrial bonds were included in the so-called "legal list." The result was that the bond investments of most conservatively administered endowments a quarter century ago were largely railroad bonds.

The great depression of I929-I933 changed many things. Concepts of what constituted a conservative investment program underwent basic changes. New standards for measuring safety of principal were developed. Ideas as to the value and the limitations of diversification as a safety device were re-examined. Investment objectives were re-appraised and re-defined, and new investment policies and practices were developed to implement these objectives. Governmental influence, leading to governmental control, over interest rates, appeared. Commodity prices, and the cost of living, increased. Many endowed institutions, in common with retired pensioners, found their dollar income either stable or declining at a time when the dollar costs of their expenditures were increasing. Under the urgency of this double spur, there has been much sober thinking, and some appropriate action, on the part of those responsible for the management of endowed funds.

In the establishment and growth of endowments, whether in the educational, health, or general welfare fields, the customary emphasis has, quite properly, been placed upon the purpose to be served by the endowment. In other words, the emphasis has been upon useful and efficient employment of funds, rather than upon the management of capital. The real work of the endowment can, therefore, be said to have commenced when funds, either income or principal or both, have become

- National Bureau of Economic Research, Corporate Bond Study.

Ibid. 
available for the charitable or educational purpose for which the endowment was established. The management of the income producing capital funds which provide the sine qua non of the endowment's operations has often been delegated to a group of trustees or a committee, or some outside agency or individual. When the management of capital becomes a part-time job, with divided responsibility, the chances for successfully competing with full-time, professional money managers, come under a tremendous handicap.

In the rapidly changing economic scene which characterizes our economy, successful investment has become a dynamic activity calling for training, technical competence, judgment, and imagination, to mention but a few of the more obvious qualifications. No longer is it possible, if it ever was, casually to open the daily paper to the financial section, select a few well known corporate bonds, check the adequacy of their rating by the financial services and their inclusion in a representative "legal list," and then complacently clip interest coupons semiannually until maturity, at which time full cash payment of principal will be received. No longer is any investment good enough to purchase and then forget, nor should the placing of hard earned capital dollars at work, and hence at risk, be undertaken as casually as the purchase of a suit of clothes. Furthermore, interest rates on investment quality bonds have declined to a point where few, if any, endowments are able to function and continue to work towards their philanthropic objectives, on the lean diet provided by such yields. The pressure of outside events has, therefore, forced endowment trustees and managements to consider the sources of their income, and ways and means of assuring its future availability in a reasonably adequate amount.

This sometimes forced consideration of investment operations has not been an unmixed evil. It has, in some cases, resulted in improvements, which were long overdue, in policies and practices, but which might have gone uncorrected for an indefinite further period, had not the exigencies of maintaining or increasing income brought about a review of prevailing activities. In some cases, there was no policy to review or modify, investment having been on a purely informal basis, controlled only by the expedience of the moment as individual decisions had to be made on the purchase, sale, or reinvestment of specific securities.

Because of the diversity of objectives and of legal or other limitations as among endowed funds, no single investment policy will apply to the field as a whole. However, because generalizations must be made in speaking of endowments as a group, it does not follow that individual endowed funds should be content with an indefinite or ambiguous method of investment operation. An investment plan, or policy, or program, or blueprint is not something which can be, or should be, acquired in standardized form, as one would select a size $7 \frac{1 / 4}{4}$ hat or size ro shoes. Nor should an investment plan be adopted simply because it is "fashionable" to have one, and to be able to refer to "our investment policy," with the implication that all well run endowments should be so equipped. 
An investment policy is a strictly functional device. It is not something that is superimposed from the outside. It should be the outgrowth of definite, individual needs in the management of money, and it should help form the bridge between the non-profit objectives of the endowment and the tangible, profit-produced dollars which make possible the partial materialization of these objectives in a practical world.

In order to have some basis for comparing the general outline of any individual investment concept with the opinions of others in the same field, faced with more or less the same problems, it is of interest to note the results of decisions reached by representative investment managers. Several guideposts for this purpose are, fortunately, available.

The first is a study prepared in 1947 by Scudder, Stevens \& Clark, Investment Counsel, entitled, "Survey of University and College Endowment Funds." This survey includes data obtained from 59 institutions whose endowment funds totaled approximately 1,300 million dollars. This sum represented 77 per cent of all college and university endowment funds according to Scudder, Stevens \& Clark's estimate as of that date. The coverage of endowment funds of over ro million dollars was judged as being 84 per cent.

In I93I the investment firm of Wood, Struthers \& Company made and published a survey of the investment portfolios of universities and colleges. The coverage was not the same as that of the Scudder, Stevens \& Clark study, since it included only 30 institutions, rather than 59. It did, however, cover colleges and universities reporting 74 per cent of the combined investments of all institutions of higher education in the United States having endowments in excess of 5 million dollars each.

Indicative of changes in investment philosophy on the part of the managers of these endowed funds are the shifts in emphasis as among major investment groups during the 15 year period between these two studies. For purposes of comparison, all investments have been listed under one of four general headings:

High Grade Securities-This includes cash, United States Government bonds, utility, railroad and industrial, foreign and municipal bonds rated as high grade, and utility, railroad and industrial preferred stocks which enjoy a margin of safety wide enough so that assurance of continued dividend payments is comparable with the assurance of interest payments on high grade bonds.

Senior Risk Securities-This includes all bonds and preferred stocks not included above as high grade.

Common Stocks.

Real Estate Mortgages, Real Estate, and Miscellaneous-Because of the impossibility in this survey of appraising the quality of various real estate mortgages, parcels of real estate, and miscellaneous assets, these have been put into a separate functional group.

In I93 the institutions included in the Wood, Struthers survey had $361 / 2$ per cent of total endowed funds represented by "High Grade" items as defined above. In I946 the Scudder, Stevens \& Clark group showed an almost identical percentage, 
namely 37 per cent. However, the internal composition of this "High Grade" classification underwent substantial changes during the intervening 15 years. Railroad bonds declined from $121 / 2$ per cent of total investments to I per cent, utility bonds from $10 \frac{1 / 2}{2}$ to 3 , per cent, industrial bonds from 4 per cent to $\mathrm{r}$ per cent, and preferred stocks from $2 \frac{1}{2}$ per cent to I per cent. The only classification in the "High Grade" grouping to show an increase between I93I and I946 was United States Government securities which increased their proportion of total investments from $2 \frac{1}{2}$ per cent to 27 per cent. As a result, in 1946 the "High Grade" portion of total invested assets, although but little changed over a 15 year period in size in relation to funds as a whole, had become predominantly an aggregation of United States Government securities.

Securities occupying a senior position in company capitalizations, but involving a material degree of risk, i.e., "Senior Risk" securities, declined in relative size between $193 \mathrm{I}$ and 1946 . In the former year they accounted for just one quarter of total investments. The largest items in this classification were utility bonds ( 7 per cent of total investments), industrial bonds ( 5 per cent), and railroad bonds ( $31 \frac{1}{2}$ per cent). All preferred stocks in this "Senior Risk" group were 6 per cent of total investments. By 1946 the total of "Senior Risk" securities had been reduced from 25 per cent of total investments to 19 per cent. Railroad, utility and industrial bonds in the group declined from an aggregate of $15 \frac{1}{2}$ per cent of total investments to 8 per cent, while preferred stocks rose from 6 per cent to ro per cent.

Real estate, mortgages, and miscellaneous investments are considered as a third group in the Scudder, Stevens \& Clark-Wood, Struthers studies. In I93r this group represented 27 per cent of total assets. By 1946 its relative size had been halved-to $13 \frac{1 / 2}{2}$ per cent. This shrinkage was caused by a moderate decline, from $91 / 2$ per cent to 8 per cent in real estate, and a major decrease in mortgages, from $\mathrm{I} 7$ per cent to $5^{1 / 2}$ per cent.

The final major investment classification is common stocks. In I93I they accounted for $\mathrm{Ir}^{1} / 2$ per cent of total assets-the smallest of the four major groups. By 1946 they had nearly tripled in size-to 30 per cent. Not all common stock subgroups increased during these 15 years. Railroad common stocks declined slightly, from 2 per cent of total assets to $1 \frac{1}{2}$ per cent. The great increase took place in industrial common stocks, which accounted for 20 per cent of total assets in 1946 as against only $4 \frac{1}{2}$ per cent in 193r.

The chief reason for this trend away from "Senior Risk" securities and mortgages into common stocks, and particularly into industrial common stocks, was, no doubt, the attempt to maintain or increase dollar income and principal values at a time when income from high grade bonds and preferred stocks was declining, due to governmental decisions, and the purchasing power of such income dollars as were earned was also shrinking.

Mr. James J. Faggiano of the Old Colony Trust Company of Boston, in a thesis 
entitled, "Investment Trends in College and University Endowment Funds," submitted to the Graduate School of Banking at Rutgers University in I948, estimated the degree of change in endowment income return and purchasing power between the years 1926 and $1947^{\circ}$ The year Ig26 was taken as a base. In this year the rate of income on a representative group of college endowments was 5.14 per cent. In I947 the rate had fallen to 4.00 per cent, or 77.9 per cent of the base figure. A large portion of college endowment income is spent for services. Mr. Faggiano next compared this reduced rate of return with the Survey of Current Business index of the average annual earnings of full-time employes of educational institutions. Taking I 929 as a base ( $I 926$ not available) the index of average earnings rose to 134.5 per cent in 1946 ( 1947 not available). The combination of a lower rate of income and higher salary costs reduced Mr. Faggiano's "Index of Endowment Utility" for services to $5^{8}$ in 1946 from 100 in 1929 . A second major area of costs in college operation falls in the field of commodities-fuel, supplies, etc. Using the Index of Wholesale Commodity Prices of the United States Bureau of Labor Statistics, Mr. Faggiano's "Index of Endowment Utility" for commodities in I947 was 5 I. 5 per cent of its 1926 level. During the past four or five years there has not been any great change in money rates, nor, presumably, in the average rate of return on endowed funds which doubtless remains in the neighborhood of 4.00 per cent. Wages, salaries, and commodity prices, however, have continued to soar. 'The Bureau of Labor Statistics' Index of Wholesale Commodity Prices, which was 151.6 in 1947 when Mr. Faggiano's Index of Endowment Utility for commodities was 5 I. 5 per cent, had risen to I82.4 by mid I95I. Taking into account the reduction in the rate of income of college endowments in the past twenty-five years and the rise in the rate of college operating expenses, it is evident that the Index of Endowment Utility has been roughly cut in half during that time.

Despite these rather disheartening trends, income from endowments remains a major factor in the operations of our colleges. According to a report of the Committee on Education of the House of Representatives 22.7 per cent of the total income of privately administered colleges and universities in the United States in 1942 was obtained from income on endowment. ${ }^{7}$ This compares with 29.8 per cent in $1920{ }^{8}$ and suggests that endowment income today is in the vicinity of one fifth the total income of colleges and universities.

Most of the statistical material previously discussed deals with average, or with overall experience. There is, however, a wide divergence in the investment position of individual endowed institutions. The Scudder, Stevens \& Clark survey of 1947 disclosed some interesting differences in portfolio composition between various colleges, based on size of endowment. Endowment funds with assets of to million

\footnotetext{
CP. I03, App. A.

${ }^{7}$ Effect of Certain War Activities Upon Colleges and Untversities, Report from the Commatree on EDUCatron, H. R. Rep. No. 214, 79th Cong., Ist Sess. 56 (1945).

Ibid.
} 
dollars or more averaged 9 percentage points more in high grade securities than did those funds of less than Io million dollars. The smaller funds, on the other hand, had larger holdings of "Senior Risk" securities, as well as real estate and common stocks. As a result of this variation in asset distribution larger funds in 1946 earned at the annual rate of 3.94 per cent of book value as against 4.06 per cent for the smaller funds. ${ }^{9}$ Scudder, Stevens \& Clark state, ${ }^{10}$

One of the outstanding facts revealed by this survey is the wide variation in investment proportions held by these 59 universities and colleges.

Certain extreme examples follow.

The average holding of the 59 schools in high grade securities in 1946 was 37 per cent. One small college had $8 \mathrm{I}^{1 / 2}$ per cent of total assets in high grade securities, and two large colleges had 77 per cent and 75 per cent. At the other extreme, five colleges had less than to per cent of assets in high grade securities. The average holding of all 59 colleges and universities in "Senior Risk" securities was Ig per cent. However, one medium sized school had $5^{6}$ per cent of its assets in this type of obligation and four others had holdings of one third or more of total funds in this group. Real estate and mortgages averaged $13^{1 / 2}$ per cent of the total assets of all 59 schools, but one large college had 70 per cent of its assets in this form of investment, and four other colleges of varying sizes had from 42 per cent to $5^{8}$ per cent. Common stocks averaged 30 per cent of total assets for the group as a whole. One small college, however, had 72 per cent of total assets in commons while seven others, also small with but one exception, had half or more of total investments in the common stock classification. Five colleges had less than ro per cent of total investments in common stocks and an additional six had from to to 20 per cent. Most of these eleven schools were medium or large in size.

The Exchange, a monthly publication of the New York Stock Exchange, in its April I95I issue contains an article entitled, "Most Popular Stocks in Endowments." Data are given for seven large eastern universities, and three major philanthropic foundations, on their "major" common stock commitments. A sliding scale of the number of shares of stock considered a "major" holding was employed, requiring a block of 20,000 shares for the largest institution to 1,000 shares for the smallest. No single stock constituted a "major" holding for all ten institutions, but General Electric, Standard Oil of New Jersey, and Union Carbide \& Carbon qualified for all but one. Sears, Roebuck \& Co. was owned in "major" size by all but two of the ten institutions, and Standard Oil Company of Indiana and Du Pont by all but three. Taking the ten institutions as a single group, the largest common share holding was in Standard Oil Company of New Jersey, followed in order by General Electric Company, Union Carbide \& Carbon, Sears Roebuck, Standard Oil Company of Indiana, Du Pont, International Harvester, Westinghouse Electric, and Socony Vacuum.11

With the growth in common stock commitments which has characterized most
'Pp. 24-25.
${ }^{10} l d$. at 8.
${ }^{11}$ The Exchange, April, x951, pp. 13-15. 
endowed funds in recent years there has been developed not only the problem of selection of individual securities, but also the problem of timing in effecting sales and purchases. Moreover, the ultimate maximum size of equity investments in relation to total holdings has become of more than academic importance. Various approaches to these problems have been made. So-called "formula plans" have been developed as affording a check upon judgment or, in some cases, a substitute for judgment. Faggiano in his thesis, "Investment Trends in College and University Endowment Funds," describes the objectives of such plans as follows: ${ }^{12}$

The control of investments in equities by a mathematical formula is merely a means of attempting to improve the "timing" of such investments, either as to their sale or purchase, with an effort to eliminate the influence of emotional judgment.

Formula plans are generally of one of two types; constant stock-bond ratio plan or variable stock-bond ratio plan. A typical constant ratio plan would establish the "normal" desired relationship between fixed interest obligations and equities for a given account. Let us assume that a 50-50 relationship was selected. The account would be reviewed and revalued at regular stated intervals, possibly quarterly or semiannually. When the relationship changed by 5 percentage points (for example, equities 55 per cent of total market value, fixed interest securities 45 per cent) then sales and reinvestments would be made in an amount sufficient to restore the original ratio. Faggiano points out ${ }^{13}$ that in order to bring about a change of 5 percentage points in a 50-50 stock-bond plan, stocks would have to increase more than 20 per cent in market value, assuming no change in bond values. The actual change in percentages brought about by a Io per cent advance in stock prices would be 52.38 per cent and 47.62 per cent, while a 20 per cent advance in stock prices would create a 54.55 per cent and 45.45 per cent relationship. In discussing the constant ratio plan Faggiano states, ${ }^{14}$

Among the drawbacks often pointed to in the constant stock ratio plans is the fact that with the same ratio of bonds to stocks at virtually all times it means that the money risk in stocks may be high at the top of a bull market when it might be desirable to have fewer stocks, and static at the bottom of a bear market when it might be desirable to own more stocks. The chances of capital growth under the constant-ratio plan, in other words, are quite modest in comparison to the potentials in the more complicated and intricate type of plan.

Discussing the variable stock-bond ratio plan, Faggiano continues, ${ }^{15}$

Variable bond-stock ratio plans are designed to overcome the objections to proportions in stocks that would be constant at the top of a market as they are at the bottom and refined to accentuate the emphasis in the direction of utmost gains and minimized losses. In other words, the attempt under the variable plans is to decrease proportions in stocks as prices rise, and increase as prices decline. This usually requires more guesswork as to the swings in the market ... and may result in embarrassment in the eventuality that the market does not perform as predicted. Of course, provided one waits long enough the opportunity to carry through such a plan would be presented ultimately.... The loss of
${ }^{28}$ P. 86.
${ }^{12} \mathrm{Pp} .88,89$.
${ }^{14}$ P. 89.
${ }^{15}$ Pp. 89, g0. 
income from such a plan ... at the top of a market creates a serious problem for an institution dependent upon its income.

As a simplified illustration of theory, a variable plan might call for the following stock-bond ratios: Dow Jones Industrial Stock Average 150, stock-bond ratio 50-50; Dow Jones 100, ratio 75-25; Dow Jones 200, ratio 25-75. Historical precedent would have to be considered to a substantial degree in setting the minimum and maximum stock-bond ratios. However, stock price averages have not always fluctuated in complete cycles. Despite Faggiano's assertion that ultimately a variable ratio plan would function, there is evidence that certain stock levels previously regarded as within the range of normal fluctuation, may not recur. On this point, Oliver J. Gingold, writing in the Wall Street Journal of July 30, r95 in his column "Abreast of the Market," says: $:^{16}$

Since its compilation in 1897 the industrial average has closed under 200 at least once each year. ... It is submitted that there will come a year in which the low price recorded for the industrial average will be 200 or above. . . Until $\mathrm{x} 925$, the 29 th year that the industrial average had been compiled, it never had failed to sell under roo. Until I927, one would always have been safe in waiting for a close under $15^{\circ}$ before making commitments. But the next time it violated either level was in 1939. In the intervening ... years, the average much more than doubled in price. . . .

Looked at in opposite fashion, there never was a year until Ig06 when industrials sold as high as roo on the average. This would have made it logical for present-day apologists for the 200 level to suggest that a sale at 99.99 was eminently sound. By the same token the average never topped 150 until 1925, nor 200 until 1927, nor 300 until 1928. It is also true that the industrial average set a new record high in 13 of the first 32 years it was compiled, yet more than two decades have passed since a new high was set. ...

The warning implicit in these figures is simply that it may be dangerous to make a fetish of a high-water mark in a growing economy, particularly one into which periodic wars have frozen a certain amount of inflation. Only in the five-year span, r938-r942, have the annual industrial average highs shown a declining trend for more than three years.

The policy "if you can't beat them, join them" is suggested in the theory that rather than try to judge "timing" it is better to ignore it, through making purchases at regular intervals, irrespective of price levels. Such a theory would apply particularly to growing funds, such as pension funds, where new money becomes available for investment at fixed times. Purchases made on such a basis will, of course, produce cost prices for securities in line with past average prices on purchase dates. In an article entitled, "Common Stocks in Pension Funds" in the July 26, 195I Commercial and Financial Chronicle, Mr. David L. Terwilleger of Kidder, Peabody \& Co. argues in favor of investing regular amounts annually in common stocks. Figures which he presents show that such investments, under the conditions assumed, would have provided a fund with greater income and greater capital enhancement than an equal investment in bonds. In describing his method Mr. Terwilleger states: $:^{17}$

$$
{ }^{16} \mathrm{P} . \mathrm{II}, \text { cols. } 3 \text { and } 4 \text {. }
$$$$
\text { 17 P. } 4 \text {, cols. } 4 \text { and } 5 .
$$ 
... Over the 3 I year period, I920 through 1950 , \$100,000 invested at Dec. 3 I each year in the stocks which make up Dow-Jones Industrial Average would have had a market value of $\$ 5,637,363$ at the end of the period. This is $\$ 2,537,363$ or $82 \%$ more than the total of $\$ 3,100,000$ invested during the period. The same amount of money would have a value of $\$ 3,73 \mathrm{r}, \mathrm{r} 88 \mathrm{had}$ it been invested at the same times in the bonds contained in Standard \& Poor's Corporate Bond Average. . . . Stock prices would have to recede $45 \%$, or to I29.48 for the Dow, in order to eliminate all profit. . . . The average Dow-Jones Industrial stock price for the period was $148.47 \ldots$. . Bond prices could decline only $17 \%$ before gains are wiped out. This would be to roo.7 for the bond average. The average return over these $3^{I}$ years from dividends on stocks in the table was $6.0 \%$, or one-third greater than the $4.5 \%$ on bonds (on a current yield basis). Dividends on stocks totalled $\$ 3,258,735$, or $53 \%$ more than the $\$ 2,127,640$ cash income from bonds. . . . Total income from dividends plus market appreciation for stocks is $\$ 5,796,098$. The comparable figure for bonds is $\$ 2,758,828$. This large differential of $\$ 3,037,260$ is a combined improvement of $110 \%$ in favor of stocks over bonds. ... In a portfolio of high grade bonds with maturities spaced it is possible to obtain a yield of $21 / 2 \%$, today. It is also possible to obtain a dividend return of $6 \%$ from a representative ilst of high grade common stocks. . . . If Pension Fund " $\mathrm{A}$ " is $\$ \mathrm{r}, 000,000$ invested in bonds, yielding $21 / 2 \%$, the income compounded annually over a $3 \mathrm{I}$-year period will amount to $\$ \mathrm{I}, 150,00 \%$. If Pension Fund " $\mathrm{B}$ " is $\$ 1,000,000$ invested $75 \%$ in bonds yielding $21 / 2 \%$ and only $25 \%$ in stocks yielding $6 \%$, the income compounded annually from the bond segment $(\$ 750,000)$ will amount to $\$ 862,505$ and the income from the stock segment (only $\$ 250,000$ ) will amount to $\$ 1,272,025$. Total income received will be $\$ 2,134,530$. Fund " $\mathrm{B}$ " will produce $\$ 984,523$, or approximately $84 \%$, more income than Fund " $\mathrm{A}$ " merely by investing $25 \%$ in stocks. The relatively small amount of Fund " $B$ " invested in stocks will produce more income than the whole of Fund "A."

The primary investment requirement of endowed funds is to maintain and increase dollar income without excessive risk to principal. This requirement becomes all the more imperative during a period such as the present when a larger number of dollars is required each year to accomplish a given task. This requirement, however, becomes more difficult of achievement when the rate of income from the major earning asset of endowments, namely, high grade bonds, is depressed and kept at an artificially low rate. During the past twenty years endowed funds have turned increasingly towards common stocks as a means of bolstering income. This greater dependence upon equities has created problems of selection of individual securities, of timing in connection with purchases and sales, and of stability of income at various levels of business activity. Various technical devices have been developed to assist in the solution of these problems, but none appears sufficiently flexible or adaptable to provide a total answer to the varying requirements of individual funds. Judgment and experience will continue to be the most valuable tools available for the job to be done. In view of the indispensable contributions which our endowed institutions have made, are making, and have the opportunity to make to our civilization, it is to be hoped that time, effort, and skill will be brought to bear in full measure upon the investment management operations of our endowed institutions. 